Research Paper

\title{
Kinetic properties of Streptomyces canarius L- Glutaminase and its anticancer efficiency
}

\author{
Fifi M. Reda \\ Department of Botany and Microbiology, Zagazig University, Zagazig, Egypt.
}

Submitted: August 6, 2013; Approved: December 28, 2014.

\begin{abstract}
L-glutaminase was produced by Streptomyces canarius FR (KC460654) with an apparent molecular mass of $44 \mathrm{kDa}$. It has 17.9 purification fold with a final specific activity $132.2 \mathrm{U} / \mathrm{mg}$ proteins and $28 \%$ yield recovery. The purified L-glutaminase showed a maximal activity against L-glutamine when incubated at $\mathrm{pH} 8.0$ at $40^{\circ} \mathrm{C}$ for $30 \mathrm{~min}$. It maintained its stability at wide range of $\mathrm{pH}$ from 5.011.0 and thermal stable up to $60^{\circ} \mathrm{C}$ with Tm value $57.5^{\circ} \mathrm{C}$. It has high affinity and catalytic activity for L- glutamine ( $\mathrm{Km} 0.129 \mathrm{mM}, \operatorname{Vmax} 2.02 \mathrm{U} / \mathrm{mg} / \mathrm{min})$, followed by L- asparagine and L-aspartic acid. In vivo, L-glutaminase showed no observed changes in liver; kidney functions; hematological parameters and slight effect on RBCs and level of platelets after 10 days of rabbit's injection. The anticancer activity of L-glutaminase was also tested against five types of human cancer cell lines using MTT assay in vitro. L-glutaminase has a significant efficiency against Hep-G2 cell ( $\mathrm{IC}_{50}, 6.8$ $\mu \mathrm{g} / \mathrm{mL}$ ) and HeLa cells $\left(\mathrm{IC}_{50}, 8.3 \mu \mathrm{g} / \mathrm{mL}\right.$ ), while the growth of MCF-7 cells was not affected. L-glutaminase has a moderate cytotoxic effect against HCT-116 cell $\left(\mathrm{IC}_{50}, 64.7 \mu \mathrm{g} / \mathrm{mL}\right)$ and RAW 264.7 cell $\left(\mathrm{IC}_{50}, 59.3 \mu \mathrm{g} / \mathrm{mL}\right)$.
\end{abstract}

Key words: L-glutaminase, anti-cancer, cytotoxicity, MTT assay.

\section{Introduction}

Microbial sources like actinomycetes are well recognized to produce a variety of chemical structures, several of which are most valuable pharmaceuticals, agrochemicals and industrial products like enzymes (Thadikamala and Reddy, 2011). Actinomycetes are considered to be preferred enzymes sources due to their production of extracellular enzymes. Many enzymes produced by actinomycetes and have been used as drugs like wise Lglutamine amidohydrolase (E.C. 3.5.1.2), commonly referred to as L-glutaminase (Sunil Dutt et al., 2014). Since the discovery of its anti-tumor properties, L-glutaminases have been in prime focus (Lazarus and Panasci, 1986). Nowadays, L-glutaminase is used as enzyme therapy for cancer especially for acute lymphocytic leukemia (Robert et al., 2001; Kyoko et al., 2004).

Where, high rate of glutamine consumption is a characteristic nature of some types of cancerous cells (Lazarus and Panasci, 1986). Based on this character experimental therapies have been developed to deprive L-glutamine to tumor cells (Iyer and Singhal, 2008). Inhibition of the tumor cell uptake of glutamine is one of the possible ways to stop the growth and this is the best accomplished by the use of L-glutaminase. This in fact, results in a selective starvation of the tumor cells because unlike normal cells lack properly functioning glutamine biosynthetic machinery (Tanaka et al., 1988; Dang, 2010). Microbial therapeutic enzymes have a broad variety of specific uses as oncolytics, thrombolytics or anticoagulant, and largely as anticancer (Sabu, 2003; Sabu et al., 2005).

The production of enzyme was influenced by a variety of physicochemical and nutritional factors. The factors affecting the production in recent years had received attention as of its great demand in clinical application and also in food industries. It is known that, the factors involved in the process of production, would not only enhance the quantity, but also quality of enzyme because of which it becomes more suitable for a specific application. Optimization of parameters can in turn influence enzyme 
synthesis and cell yield (Okami, 1986). The strain of actinomycetes was used for glutamic acid production under optimum growth conditions (Divya Teja et al., 2014). From the compatibility perspective in mass production and as well as beneficial application aspect extracellular enzyme producer as choice of source is always attractive (Pandey, 2003). The objective of this study was to utilize Streptomyces canarius FR with good ability to produce extracellular L-glutaminase and characterize the purification. Biochemical, kinetics and in vitro anticarcenogenic properties of L- glutaminase will be also examined.

\section{Materials and Methods}

\section{Collection, isolation and identification of $S$. canarius FR}

Streptomyces canarius FR isolated from Tell Basta, Zagazig, Sharkyia Governorate, Egypt was identified according to identification keys (Kämpfer, 2006). The identification was confirmed by the analysis of 16S rRNA gene sequence (Altschul et al., 1997).

The strain was preliminary tested for L-glutaminase production by streaking on minimal glutamine agar medium (MGA) plates. Components of MGA $(\mathrm{g} / \mathrm{L})$ include: $\mathrm{KCl} 0.5 ; \mathrm{MgSO}_{4} 7 \mathrm{H}_{2} \mathrm{O} 0.5 ; \mathrm{KH}_{2} \mathrm{PO}_{4} 1.0 ; \mathrm{FeSO}_{4} 7 \mathrm{H}_{2} \mathrm{O}$ 0.1; $\mathrm{ZnSO}_{4} 7 \mathrm{H}_{2} \mathrm{O}$ 1.0; glutamine 5 and phenol red 0.012. The plates were incubated at $30{ }^{\circ} \mathrm{C}$ for 5 days. Formation of pink zones around the microbial growth indicated the positive reaction (Balagurunathan and Subramanian, 1993; Balagurunathan et al., 2010).

\section{Optimization of culture conditions for L-glutaminase production}

Streptomyces canarius FR was cultivated in Lglutaminase production modified Czapek's medium contained $(\mathrm{g} / \mathrm{L})$ : L-glutamine 10; D-glucose $5 ; \mathrm{MgSO}_{4} 7 \mathrm{H}_{2} \mathrm{O}$ $0.5 ; \mathrm{KCl} 0.05 ; \mathrm{KH}_{2} \mathrm{PO}_{4}$ 1.0. Enzyme production was tested under different cultured conditions; different incubation periods (0-8 days); different temperatures $\left(25-55^{\circ} \mathrm{C}\right)$; different $\mathrm{pH}$-values ( $\mathrm{pH} 4-10)$ under shaking and static conditions. The culture was harvested and centrifuged at $10,000 \mathrm{rpm}$ for $30 \mathrm{~min}$ the obtained cell free filtrate was used as crude enzyme according to Dura et al. (2002).

\section{Activity assay and Protein determination of L- glutaminase}

The activity of glutaminase enzyme is determined by estimating the amount of $\mathrm{NH}_{3}$ liberated from glutamine (Borek et al., 2004). Protein concentration was determined by Lowery et al. (1951) using bovine serum albumin (Sigma chemical Co.) as a standard.

\section{L- Glutaminase purification}

Two liters from the nutritionally optimized submerged 5 days culture of $S$. canarius FR growing in L- glutaminase producing medium was prepared. The precipitated protein was collected by centrifugation at 10,000 rpm at $4{ }^{\circ} \mathrm{C}$ and dissolved in a minimum volume of phosphate buffer (0.01 M, pH 8.0) (Sabu et al., 2005). L- glutaminase was fractionated by salting out $(50-80 \%$ ammonium sulphate saturation). The collected precipitate was dissolved in phosphate buffer $(0.01 \mathrm{M}, \mathrm{pH} 8.0)$ and then dialyzed against the same buffer for $24 \mathrm{~h}$ at $4{ }^{\circ} \mathrm{C}$ with continuous stirring and occasional changes of the buffers. The dialyzate was fractionated by ion-exchange chromatography (DEAE-Cellulose). After column equilibration the enzyme was eluted by gradient $\mathrm{NaCl}(50-200 \mathrm{mM})$ dissolved in phosphate buffer (0.1 M, pH 8.0) with 0.001 M EDTA. The activity, homogeneity (SDS-PAGE) and protein contents of the fractions were determined as above. The most active homogenous fractions were gathered and loaded to pre-equilibrated column of Sephadex G100 gel-filtration chromatography) using the same buffer for elution. For each fraction activity was assessed as above. The most active fractions were pooled and concentrated by dialysis against buffer (Nagendra Prabhu, 1997).

\section{SDS-PAGE Analysis}

The molecular weight of L- glutaminase from culture of S. canarius was carried out using SDS-PAGE according to Lammeli (1970). PageRuler Unstained Protein Ladder, Fermentas marker was used.

\section{Biochemical and kinetic properties of the purified L-glutaminase}

The biochemical properties of purified $S$. canarius Lglutaminase as optimum $\mathrm{pH}, \mathrm{pH}$ stability, reaction temperature, thermal stability salt tolerance, metal ions and substrate specificity enzyme were determined as described by Amena et al. (2010) and Sabu et al. (2005).

The thermal stability of enzyme was examined after preincubation of the enzyme at $50-80^{\circ} \mathrm{C}$ using $0.1 \mathrm{M}$ phosphate buffer ( $\mathrm{pH} \mathrm{8.0)}$ for different time (10-90 min). The relative activity was determined after the incubation of reaction mixture at $37^{\circ} \mathrm{C}$ for $30 \mathrm{~min}$. The thermal inactivation rate $(\mathrm{Kr} \mathrm{min})$ was calculated by the first-order kinetic model (Whitaker, 1972); $\operatorname{Ln}\left(\mathrm{A}_{t} / \mathrm{A}_{\mathrm{o}}\right) \mathrm{k}_{\mathrm{t}} \mathrm{T}$, where $\mathrm{A}_{\mathrm{o}}$ and $\mathrm{A}_{\mathrm{t}}$ are the specific activity zero and $t$ time. $T 1 / 2$ was calculated from the linear equation for each temperature. The Tm was calculated from the linear equation of different preincubation temperature at $60 \mathrm{~min}$.

Stability of L-glutaminase was examined after preincubation of the enzyme for $2 \mathrm{~h}$ at $\mathrm{pH}$ from 4.0-11.0. Acetate $(0.2 \mathrm{M})$, phosphate $(0.2 \mathrm{M})$ and glycine- $\mathrm{NaOH}$ buffers were used to covering $\mathrm{pH}$ range (4-5), (6-8) and (9-11) respectively. After adding glutamine $(40 \mathrm{mM})$ the reaction mixture was incubated at $37^{\circ} \mathrm{C}$ for $30 \mathrm{~min}$. The activity of the enzyme was determined for each $\mathrm{pH}$.

To assay the metal ions effect, the purified enzyme was pre-incubated with each metal ion separately for 
30 min before adding glutamine $(40 \mathrm{mM})$. The enzyme relative activity was determined immediately after incubation at $37{ }^{\circ} \mathrm{C}$ for $30 \mathrm{~min}$.

The kinetic parameters of L-glutaminase as Vmax, $\mathrm{Km}$ and Kcat were estimated using different concentrations of glutamine, asparagine and aspartic acid, separately (10-100 mM). Michaelis-Mentel constant $(\mathrm{Km})$ and maximum velocity (Vmax) were calculated from LineweaverBurk plot. Catalytic efficiency (Kcat) was expressed by the specific activity per mol enzyme.

\section{Cytotoxicity of L- glutaminase}

Cytotoxic effect of the L-glutaminase was evaluated using $5 \mathrm{New}$ Zealand rabbits as experimental group and one rabbit as control. Experimental group were injected intravenous with $1 \mathrm{~mL}$ of L- glutaminase $(132.2 \mathrm{U} / \mathrm{mg}$ protein $/ 1.5 \pm 0.1 \mathrm{~kg}$ ) every 5 days for two weeks. After the two weeks, blood samples were collected 10;25; 40 and 50 day of the last injection. Plasma were collected and stored at -20 ${ }^{\circ} \mathrm{C}$. RBC, WBC, platelets, hemoglobin ALT, AST, GGT, total protein, albumin, cholesterol, glucose and creatinine were determined as described by Birt (1967) and Reitman and Frankel (1957). Hemolytic activity of the purified Lglutaminase was evaluated using a blood agar assay (Tay et al., 1995).

\section{Histopathological examination:}

Histological examination for the experimental group and control was carried out on liver and kidney, 50 days of the last injection, according to Roy and Maity (2007).

\section{Anticancer efficiency}

Anticancer efficiency of L-glutaminase as antitumor was measured against: Human hepatocarcinoma cell line (HepG2); Human breast adenocarcinoma cell line (MCF-7); human colorectal carcinoma cells (HCT-116); Human cervical carcinoma cell line (HeLa) and Raw murine macrophage cells (RAW 264.7. MTT Cell Viability Assay was used as described by Hansen et al. (1989). (\% Cell viability $=$ O.D of treated cells / O.D of control cells X 100. The five human cell lines were purchased from ATCC, USA). The efficiency of L-glutaminase was determined using sigmoidal dose response curve-fitting models (Graphpad Prizm Software, version 3).

\section{Statistical Analyses}

All statistical analyses were carried out using SPSS ver. 11 on pc i5

\section{Results and Discussion}

\section{Identification of $S$. canarius FR strain}

The present study showed that, the strain is $S$. canarius FR used (after it has been identified by studying their morphological and biochemical characterization).
PCR amplification of 16S rDNA gene confirmed the identity (98\%) of $S$. canarius FR. The partial nucleotide sequence of amplified gene was submitted in GenBank (http://www.ncbi.nlm.nih.gov/GenBank/update.htm) under accession number KC748492. The results derived from the sequence analysis of the $16 \mathrm{~S}$ rDNA gene show a $\mathrm{G}+\mathrm{C}$ content of $58.9 \mathrm{~mol} \%$ which is in good agreement with the data published for Streptomyces by Kannan and Vincent (2011). The tested strain was characterized by formation of a pink zone around colonies using MGA medium due to breakdown of amide bond in L-glutamine and ammonia liberation (Ranjekar and Sridhar, 2002).

\section{Optimization of L-glutaminase production}

The submerged fermentation method for producing L- glutaminase was showed that, the L- glutaminase produced, is in its optimum phase (at $30^{\circ} \mathrm{C}$ for 5 days and $\mathrm{pH}$ 7.5 under shaking condition at $120 \mathrm{rpm}$ ) (Data was not shown). Dura et al. (2002) and Sabu (2003) stated that submerged fermentation was the routinely used methods for L-glutaminase production from various microorganisms. The result obtained by Krishnakumar et al. (2011) is in the agreement with present study. They showed that production of L-glutaminase from Streptomyces sp. SBU1 was at $30{ }^{\circ} \mathrm{C}$ after $96 \mathrm{~h}$ of incubation and initial $\mathrm{pH}$ 9.0. Balagurunathan et al. (2010) stated that, the optimum conditions for marine Streptomyces olivochromogenes Lglutaminase production were determined at $\mathrm{pH} 7$, temperature $30{ }^{\circ} \mathrm{C}$ and $3.5 \%$ salinity for 5 days under shaking condition at $120 \mathrm{rpm}$. Divya Teja et al. (2014) reported that strain of actinomycetes gave maximum production at $\mathrm{pH} 7$, temperature $30{ }^{\circ} \mathrm{C}$, time $96 \mathrm{~h}$ and salinity $3.5 \%$. On the other hands, the optimum conditions ( $\mathrm{pH}$ and Temperature) for L-glutaminase family is varied from one member to another Usha-Kiranmayi et al. (2013) studied one of glutaminase family he found that, the maximum production of L- asparaginase from Pseudonocardia endophytica VUK-10 was found in the culture medium with $\mathrm{pH} 8$ and temperature $30{ }^{\circ} \mathrm{C}$ incubated for four days. Moreover, Suresh Kumer et al. (2013) stated that the response surface methodology predicted that a production containing Temperature $36.31 \mathrm{C}, \mathrm{pH}$ 7.34, Time $67.63 \mathrm{~h}$, Galactose $40.20 \mathrm{~g} / \mathrm{L}$ and L-glutamine $19.09 \mathrm{~g} / \mathrm{L}$ to be optimum for the production of Serratia marcescens L-Glutaminase. Kiruthika and Saraswathy (2013) revealed that the maximum yield of Vibrio azureus L- glutaminase production $(247 \mathrm{U} / \mathrm{mL})$ was achieved in a seawater based medium at $\mathrm{pH} 8,37{ }^{\circ} \mathrm{C}, 1 \%$ inoculum concentration and $2 \%$ glutamine concentration for $24 \mathrm{~h}$.

\section{Purification of L-glutaminase}

L-glutaminase was purified from 5 days $S$. canarius culture to assess their yield and purity. The crude Lglutaminase was undergoes fractional precipitation by salting out (50-80\% ammonium sulfate). The enzyme overall 
purification profile from $S$. canarius culture was summarized in Table 1. The crude extract contained $23.0 \mathrm{mg}$ of protein and showed a total glutaminase activity 170 units with specific activity of $7.4 \mathrm{U} / \mathrm{mg}$ protein. At all purification steps, the specific activity increased compared to crude. The maximum specific activity $132.2 \mathrm{IU} / \mathrm{mg}$ protein with a yield of $28 \%$ was attained after Sephadex G100 purification. The partial purified was increased more than 17 fold compared with crude. These results were in the agreement with that reviewed by Mohana Priya et al. (2011). Also, Kumar et al. (2012) stated that Bacillus sp. LKG-01 (MTCC 10401) L-glutaminase activity was purified 49 -fold from cell-free extract with $25 \%$ recovery with specific activity $584.2 \mathrm{U} / \mathrm{mg}$ protein after gel filtration. On the other hand, Elshafei et al. (2014) recorded that an intracellular L-glutaminase from Penicillium brevicompactum NRC829 was purified to homogeneity (162.75 fold) with an apparent molecular mass of $71 \mathrm{kDa}$. So the method used in the present study proved to be a good method in producing and purification of L-glutaminase.

\section{Determination of molecular weight for enzyme:}

The molecular homogeneity of the purified Lglutaminase from fermentation condition, as well as their purification steps were evaluated by SDS-PAGE. Single band at $44 \mathrm{kDa}$ was appeared after final purification step (Column Sephadex $\mathrm{G}_{100}$ ) (Figure 1). Similarly, the molecular mass of the native enzyme from Stenotrophomonas maltophilia NYW-81 was estimated to be $41 \mathrm{kDa}$ by gel filtration (Wakayama et al., 2005). And, Singh and Banik (2013) revealed that L-glutaminase extracellularly produced by Bacillus cereus MTCC 1305 was purified to apparent homogeneity with a fine band. The molecular weight of native enzyme and its subunit were found to be approximately 140 and $35 \mathrm{kDa}$, respectively, which indicates its homotetrameric nature.

\section{Biochemical properties of the purified L-glutaminase}

\section{Optimal $\mathrm{pH}$ and $\mathrm{pH}$ stability}

The L-glutaminase maintained its activity over a range of $\mathrm{pH} 5.0-9$ with optimum at $\mathrm{pH} 8.0$ (Figure $2 \mathrm{~A}$ ). The activity significantly decreased at both low and high $\mathrm{pH}$ values. The $\mathrm{pH}$ stability of the L-glutaminase also showed a similar trend, the enzyme was stable at wide range $\mathrm{pH}$ 5.0-11.0 with being most stable at $\mathrm{pH}$ 7.0-9.0.
Practically, at acidic $\mathrm{pH}$ values a higher rate of enzyme inactivation was appeared, comparing to alkaline side, assuming the enzyme basic identity. The negative effect on enzyme activity at lower and higher $\mathrm{pH}$ values, suggesting the effect on ionization state of enzyme, modifying the enzyme surface charge, dissociation of subunits/ coenzyme, consequently disrupt its binding with substrate. Consistently, the activity of L-glutaminase from $S$. canarius showed alkaline optimum $\mathrm{pH} 7-8$, this neutral $\mathrm{pH}$ stability of enzyme, being a favored criterion for enzyme action in vivo. Similarly, Streptomyces gulbargensis Lasparaginase was more stable at the alkaline $\mathrm{pH}$ than at the acidic one (Amena et al., 2010; Kumar et al., 2012).

\section{Optimal temperature and thermal stability}

The optimum temperature for the L-glutaminase activity was determined by incubation of the reaction mixture at various degrees $\left(25-50{ }^{\circ} \mathrm{C}\right)$ using L- glutamine as substrate in $0.1 \mathrm{M}$ potassium phosphate buffer $(\mathrm{pH} 8.0)$. The highest enzyme specific activity $(53.3 \mathrm{U} / \mathrm{mg}$ protein) was obtained at $40{ }^{\circ} \mathrm{C}$. Above and below this temperature the enzyme activity decreased (Figure $2 \mathrm{~B}$ ). Regarding to thermal stability the enzyme had a catalytically thermal stability below $60{ }^{\circ} \mathrm{C}$, with a slightly decreasing in its activity at $70{ }^{\circ} \mathrm{C}$, while completely lost its activity at $80^{\circ} \mathrm{C}$ (Figure $2 \mathrm{C}$ ). The enzyme half-life times $\left(\mathrm{T}_{1 / 2}\right)$ was $45.7,38.8,29.3$ and $17.3 \mathrm{~min}$ at $50,60,70$ and $80^{\circ} \mathrm{C}$, respectively. Also, the Tm of enzyme was $57.5^{\circ} \mathrm{C}$, assuming the retaining of about $50 \%$ of its initial activity by heating for $60 \mathrm{~min}$ (Figure 2 D). Theoretically, thermal inactivation rates $(\mathrm{Kr})$ are $0.0184,0.0227,0.0544$ and $0.0449 \mathrm{~S}^{-1}$ at $50,60,70$ and $80^{\circ} \mathrm{C}$, suggesting the dissociation of co-enzyme or denaturation of subunits by heating per unit time. These results were in consistent with those reported for Amena et al. (2010) and Kumar et al. (2012). Also, Singh and Banik (2013) recorded that the purified L- glutaminase enzyme produced by Bacillus cereus MTCC 1305 showed maximum activity at optimum $\mathrm{pH} 7.5$ and temperature $35^{\circ} \mathrm{C}$. The enzyme retained stability up to 50 and $20 \%$ even after treatment at 50 and $55^{\circ} \mathrm{C}$, respectively, for $30 \mathrm{~min}$. Furthermore, Elshafei et al. (2014) recorded that the purified Penicillium brevicompactum L- glutaminase showed its maximal activity against L-glutamine when incubated at $\mathrm{pH} 8.5$ at $50^{\circ} \mathrm{C}$ for $30 \mathrm{~min}$ indicating the thermo-stability nature of this enzyme.

Table 1 - Summary of purification steps of Streptomyces canarius L- glutaminase.

\begin{tabular}{lccccc}
\hline Purification steps & Enzyme activity (U) & Total protein $(\mathrm{mg})$ & Specific activity (U/mg protein) & Purification fold & Yield (\%) \\
\hline Crude extract & 170 & 23 & 7.4 & 1 & 100 \\
70\% Amm. Sulph.ppt & 145 & 17 & 8.5 & 1.2 & 85 \\
DEAE-Cellulose & 95 & 0.77 & 123.4 & 16.7 & 56 \\
Sephadex G100 & 47.6 & 0.36 & 132.2 & 17.9 & 28 \\
\hline
\end{tabular}




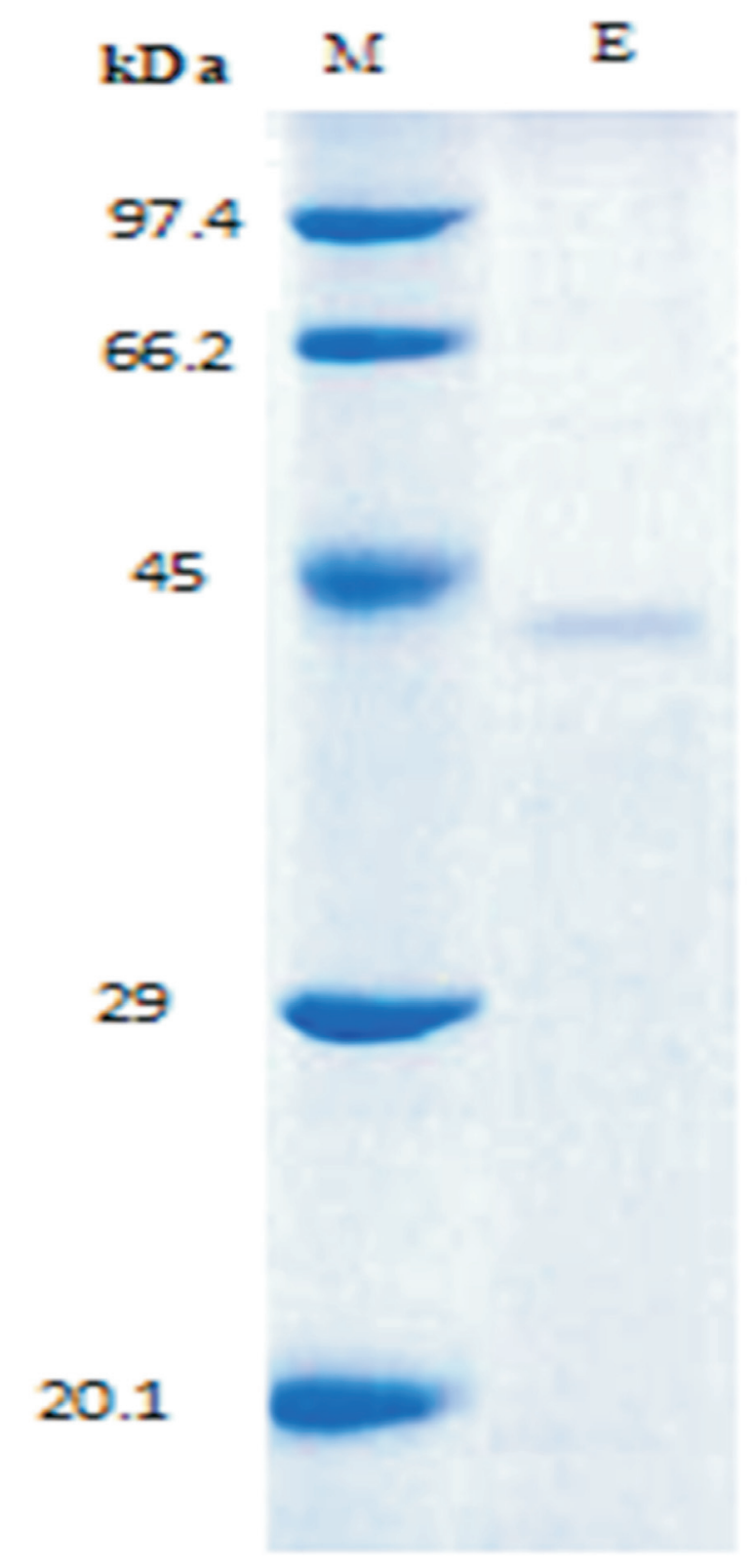

Figure 1 - SDS- PAGE of purified L-glutaminase from S. canarius. Lane $\mathrm{M}$ (marker protein), Lane E, the purified enzyme.

\section{Salt tolerance of $S$. canarius L-glutaminase}

The results represented in Figure (2 E) showed that, tolerance in glutaminase activity was observed by increasing the $\mathrm{NaCl}$ concentration up to $25 \%$. This is a good tolerance value. Similarly, Wakayama et al. (2005) observed that the L-glutaminase produced from actinomycetes has a good salt tolerance.

\section{Substrate specificity and kinetic properties of $S$. canarius L-glutaminase}

The kinetic parameters for L-glutaminase towards substrates were determined from the Lineweaver-Burk Plot
(Figure $2 \mathrm{~F}$ and Table 2). The enzyme had relative high affinity and catalytic activity for L- glutamine (Km $0.129 \mathrm{mM}$, Vmax $2.02 \mathrm{U} / \mathrm{mg} / \mathrm{min}$ ), followed by Lasparagine $(\mathrm{Km} 0.137 \mathrm{mM}$, Vmax $1.75 \mathrm{U} / \mathrm{mg} / \mathrm{min})$ and low affinity to L-aspartic acid ( $\mathrm{Km} 5.38 \mathrm{mM}$, Vmax $0.68 \mathrm{U} / \mathrm{mg} / \mathrm{min}$ ). Also, the highest catalytic efficiency (Kcat turnover number) for the enzyme was assessed for L-glutamine $\left(0.75 \times 10^{-3} \mathrm{~s}-1\right)$ followed by L-asparagine $\left(0.68 \times 10^{-3} \mathrm{~s}-1\right)$ and L-aspartic acid $\left(0.25 \times 10^{-3} \mathrm{~s}-1\right)$. The high affinity of $S$. canarius L-glutaminase to L-glutamine as substrate was detected previously by Senthil-Kumar and Selvam (2011) and Kumar et al. (2012) for Streptomyces radiopugnans MS1 and Pseudomonas sp.BTMS-51, respectively. Also, Singh and Banik (2013) revealed that the substrate specificity test of Bacillus cereus MTCC 1305 Lglutaminase showed its specificity for L-glutamine. Moreover, the small Km $(0.129 \mathrm{mmol})$ of the tested S. canarius L-glutaminase indicated high affinity of the enzyme to glutamine meaning that the rate will approach Vmax more quickly (Lehninger et al., 2005). Also, Elshafei et al. (2014) recorded that the highest activity of Penicillium brevicompactum L- glutaminase was reported towards its natural substrate, L-glutamine, with an apparent $\mathrm{Km}$ value of $1.66 \mathrm{mM}$.

\section{Influence of metal ions on L-glutaminase activity:}

The impact of various inhibitors and activators on catalytic potency of the prepared L- glutaminase was evaluated by pre incubation of the enzyme with each compound for 30 min without substrate. Results in Table 3 showed that, $\mathrm{Ca}^{+2}, \mathrm{Ba}^{+2}, \mathrm{Fe}^{+3}, \mathrm{Zn}^{+2}, \mathrm{Cu}^{+}, \mathrm{Hg}^{+2}$ and $\mathrm{Cd}^{+2}$ considered to be inhibitor. On the other hand, $\mathrm{Mn}^{+2}, \mathrm{Na}^{+}$and $\mathrm{Co}^{+2}$ were shown to be activator. These results were in agreement with Senthil-Kumar and Selvam (2011) for S. radiopugnans MS1 L-asparaginase. Also, Singh and Banik (2013) reported that monovalent cations $(\mathrm{Na}(+), \mathrm{K}(+))$ and phosphate ion activated the B. cereus MTCC 1305 Lglutaminase activity, while divalent cations $(\mathrm{Mg}(2+)$, $\mathrm{Mn}(2+), \mathrm{Zn}(2+), \mathrm{Pb}(2+), \mathrm{Ca}(2+), \mathrm{Co}(2+), \mathrm{Hg}(2+), \mathrm{Cd}(2+)$, $\mathrm{Cu}(2+))$ inhibited its activity.

\section{Cytotoxicity effect of L-glutaminase}

The cytotoxicity effect of purified $S$. canarius Lglutaminase was explored based on the hematological and blood chemistry pictures for the New Zealand rabbits (Table 4). From the biochemical profiles, generally, there is no observed effect on liver, renal functions, glucose, lipids and other electrolytes, with slight inducing effect on the activity of ALT, AST and level of Random S. Glucose. Depending on these results, the L- glutaminase had relatively no negative effect on liver functions, where AST and ALT was the most potential indicator for liver dysfunction, this in the agreement with that obtained by Pratt and Kaplan (2000).

Also, the cellular toxicity of the purified $S$. canarius L-glutaminase was evaluated by estimation of the degree of 

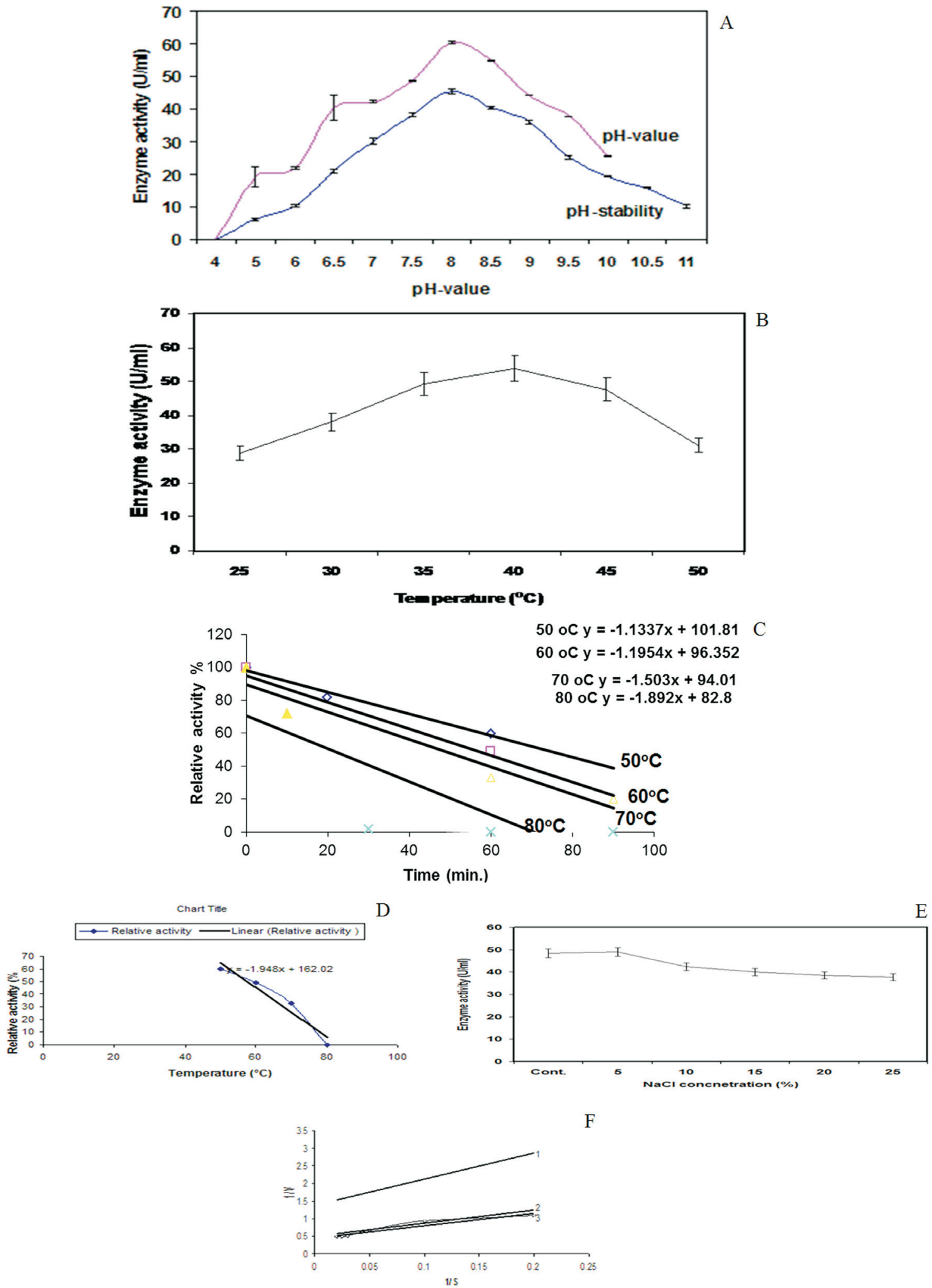

Figure 2 - Characterization of S. canarius L-glutaminase. (A) $\mathrm{pH}$ value and $\mathrm{pH}$ stability profile. The enzyme was preincubated for $2 \mathrm{~h}$ at various $\mathrm{pHs}$ (4.0 -11.0), then measuring the residual deaminating activity; (B) The optimal temperature for activity was assessed by measuring the enzyme activity at different temperatures between 25 and $50^{\circ} \mathrm{C}$; (C) Thermal stability profile. After incubation of enzyme in different temperature $\left(50-80{ }^{\circ} \mathrm{C}\right)$ at various periods (10-90 $\mathrm{min}$ ), the residual activity was determined by the standard assay method; (D) Thermal inactivation profile. Tm is temperature degree at which the enzyme retains half of its initial activity at $60 \mathrm{~min}$. (E) Different $\mathrm{NaCl}$ concentrations from $0-25 \%$; (F) Km values (Lineweaver-Burk plot) were calculated by fitting the $1 / \mathrm{S}$ of substrate $v s$. the 1 / activity of the enzyme. (1) $\mathrm{L}$ - aspartic acid $\mathrm{y}=7.4538 \mathrm{x}+1.3854 ;$ (2) L-asparagine $\mathrm{y}=3.4933 \mathrm{x}+0.4514 ;$ (3) L-glutamine $y=3.7046 x+0.5076$. 
Table 2 - Kinetics of S. canarius L- glutaminase.

\begin{tabular}{lccc}
\hline Substrates $(\mathrm{mM})$ & $\mathrm{Km}\left(\mathrm{mmol}^{-1}\right)$ & $\begin{array}{c}\operatorname{Vmax}\left(\mathrm{U} \mathrm{mg}^{-1}\right. \\
\left.\operatorname{protein~} \mathrm{min}^{-1}\right)\end{array}$ & Kcat $\left(\mathrm{s}^{-1}\right)$ \\
\hline L- glutamine & 0.129 & 2.02 & $0.75 \times 10^{-3}$ \\
L- asparagines & 0.137 & 1.83 & $0.68 \times 10^{-3}$ \\
Aspartic acid & 5.38 & 0.68 & $0.25 \times 10^{-3}$ \\
\hline
\end{tabular}

The kinetic parameters were determined by incubation of the enzyme (132.2 U/mg protein) in potassium phosphate buffer $(\mathrm{pH} \mathrm{8)}$ with various concentrations of substrate $(10-100 \mathrm{mM})$ under the standard assay conditions, then measuring the deaminating activity of the enzyme. Maximum velocity (Vmax) was expressed by activity of enzyme in $\mu$ mol of NH3 compounds formed per minute per mg protein enzyme. $\mathrm{Km}$ is the substrate concentration ( $\mathrm{mM}$ ) at half of maximum velocity. Kcat is the maximum velocity of the enzyme per mol per second.

platelet aggregations and hemolytic activity as described by Wei et al. (2007). All the hematological parameters (Table 4) were in normal range along the experimented period, however, the red blood cells, hemoglobin, white blood cells and the platelets slightly decreased within normal range after 10 days of L-glutaminase injection. The L-glutaminase displayed no hemolytic activity to human blood (Figure 3). Platelet aggregation and hemolytic activity are the most relevant biochemical assays (Pratt and Kaplan, 2000). The lack of ability to aggregate human platelets and lyses of human RBCs are unique supportive criteria from therapeutic point of view. Similar results approved the non cytotoxicity of microbial glutaminase (Baskerville et al., 1980).

Table 3 - Effect of inhibitors and activators on L- glutaminase activity.

\begin{tabular}{lc}
\hline Metal ions $(5 \mathrm{mM})$ & Relative activity $(\%)$ \\
\hline None (control) & $100.67 \mathrm{abc} \pm 0.15$ \\
$\mathrm{Ca}^{+2}$ & $75.33 \mathrm{~cd} \pm 0.76$ \\
$\mathrm{Na}^{+2}$ & $105.00 \mathrm{ab} \pm 0.50$ \\
$\mathrm{Ba}^{+2}$ & $56.70 \mathrm{~d} \pm 5.29$ \\
$\mathrm{Mg}^{+2}$ & $81.33 \mathrm{bc} \pm 60.48$ \\
$\mathrm{Hg}^{+2}$ & $20.00 \mathrm{e} \pm 0.50$ \\
$\mathrm{Co}^{+2}$ & $122.00 \mathrm{a} \pm 0.50$ \\
$\mathrm{Fe}^{+3}$ & $53.00 \mathrm{~d} \pm 0.87$ \\
$\mathrm{Mn}^{+2}$ & $125.00 \mathrm{a} \pm 0.50$ \\
$\mathrm{Cu}^{+2}$ & $50.00 \mathrm{~d} \pm 0.50$ \\
$\mathrm{Zn}^{+2}$ & $87.00 \mathrm{bc} \pm 0.92$ \\
$\mathrm{Cd}^{+2}$ & $17.00 \mathrm{e} \pm 0.50$ \\
$1 . \mathrm{s} . \mathrm{d}$ & 27.49 \\
$\mathrm{~F}$ & 12.669 \\
$\mathrm{Sig}^{+2}$ & .000 \\
\hline
\end{tabular}

The enzyme activity was determined in the absence and presence of different ions at concentration $10 \mathrm{mM}$ after a $30 \mathrm{~min}$ exposure to each ion. The relative activity was expressed as the percentage ratio of the activity of the enzyme incubated with the effectors to that of the untreated enzyme.

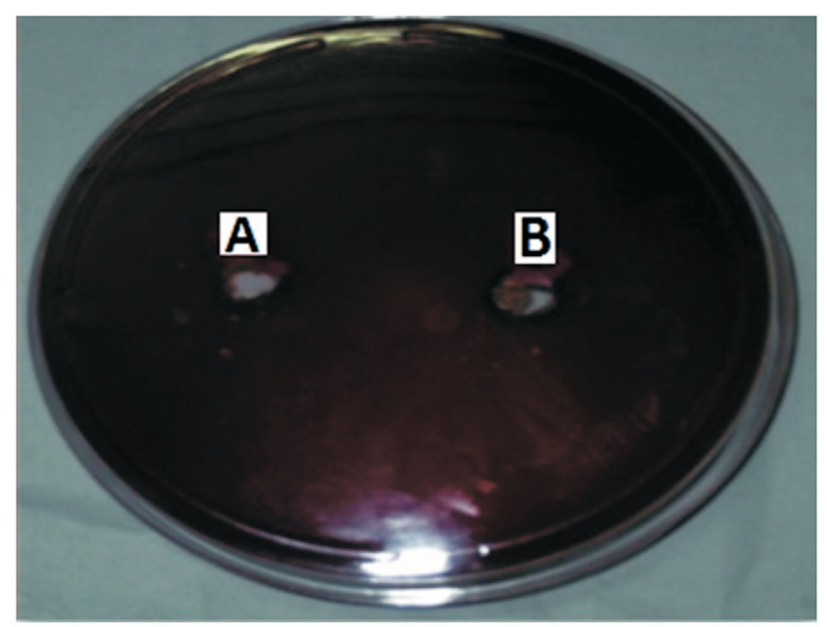

Figure 3 - Hemolytic activities of Strepromyces canarius L- glutaminase, $100 \mu \mathrm{L}$ of purified enzyme (A) and $200 \mu \mathrm{L}$ purified enzyme (B).

\section{Histological studies:}

Figures (4 and 5) show photomicrograph of liver and kidney section histological of treated and non treated rabbits after 50 days of the last injection. It can be seen from photomicrograph of renal and liver tissues, there is no observed abnormalities in these structure. Since, the kidney showing normal glomeruli surrounded by normal renal tubules lined cubical epithelial cells, whereas in treated tissue showed round distal convoluted tubules lined by cubical epithelium and longitudinal collecting duct lined by columnar epithelium (Figure 4). Photomicrograph of treated rabbit liver showing variable sized central veins surrounded by cords and rows of hepatocytes, comparing with negative control (Figure 5). These results were in similarity with that obtained by Baskerville et al. (1980) and Roy and Maity (2007).

\section{Anticancer efficiency in vitro}

Using MTT assay in the present investigation, the effect of the purified enzyme on the growth of Hep-G2, MCF7, HCT-116, HeLa and RAW 264.7 cells were studied after $48 \mathrm{~h}$ of incubation. As shown in Figure (6), the tested enzyme had a high efficiency against Hep-G2 cell ( $\mathrm{IC}_{50}, 6.8$ $\mu \mathrm{g} / \mathrm{mL}$ ) and HeLa cells $\left(\mathrm{IC}_{50}, 8.3 \mu \mathrm{g} / \mathrm{mL}\right.$ ), while the growth of MCF-7 cells was not affect by the treatment. In the other hand, the treatment of HCT-116 and RAW 264.7 cells with the tested enzyme indicated that there was a moderate cytotoxic effect as concluded from their high $\mathrm{IC}_{50}$ calculated values: $64.7 \mu \mathrm{g} / \mathrm{mL}$ and $59.3 \mu \mathrm{g} / \mathrm{mL}$, respectively, compared with the known anticancer drug paclitaxel, which its $\mathrm{IC}_{50}$ values for these cell lines ranged from 0.5-1.2 $\mu \mathrm{g} / \mathrm{mL}$. Similarly, Devi and Azmi (2012) showed that the purified L-asparaginase from Erwinia carotovora MTCC 1428 used for killing of Hep-2C cell line. Also, E. carotovora MTCC 1428 asparaginase was showed better in 


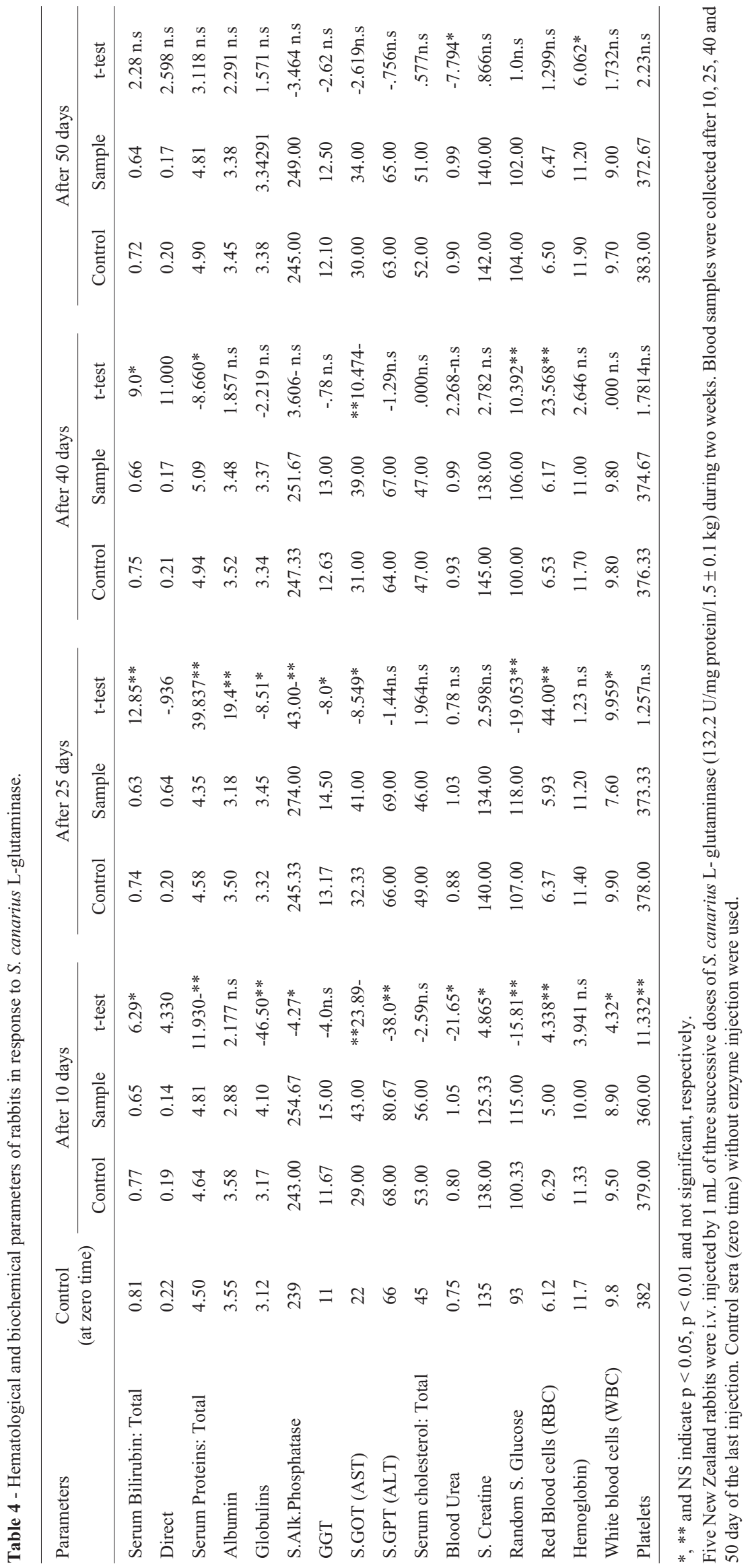



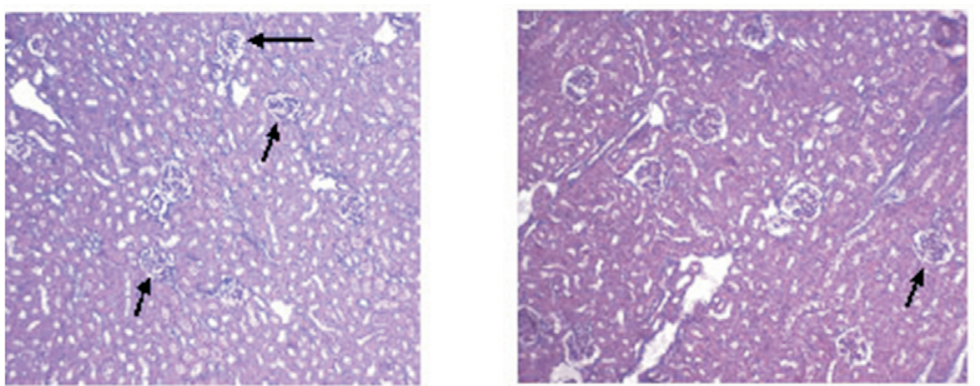

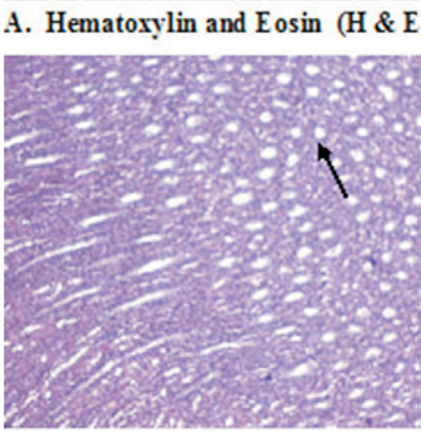

B. H \& E X 150
A. $\mathrm{H} \& \mathrm{E} \times 200$

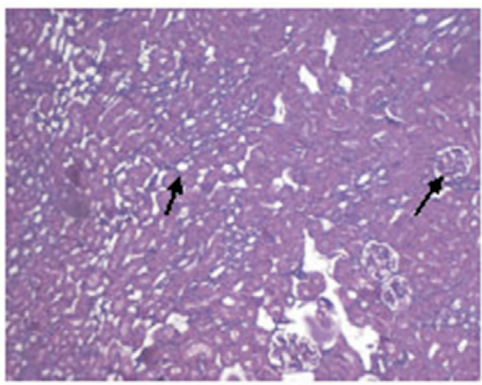

B. H \& E X 200

Figure 4 - Photomicrograph (at Hematoxylin and Eosin X 150 and X200) of renal section of, (A) negative control showing normal glomeruli ( $\uparrow$ ) surrounded by normal renal tubules lined cubical epithelial cells. (B) treated with S. canarius L-glutaminase showing round distal convoluted tubules ( $\uparrow$ ) lined by cubical epithelium and longitudinal collecting duct lined by columnar epithelium.

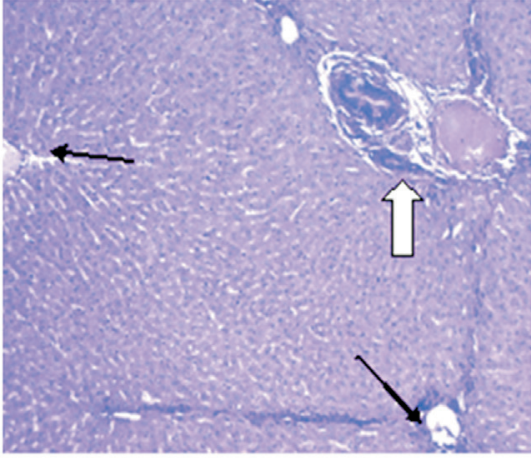

(C) H \& E X 150

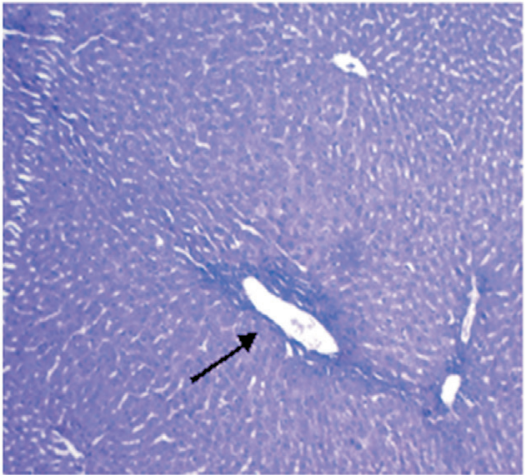

D. H \& E X 150

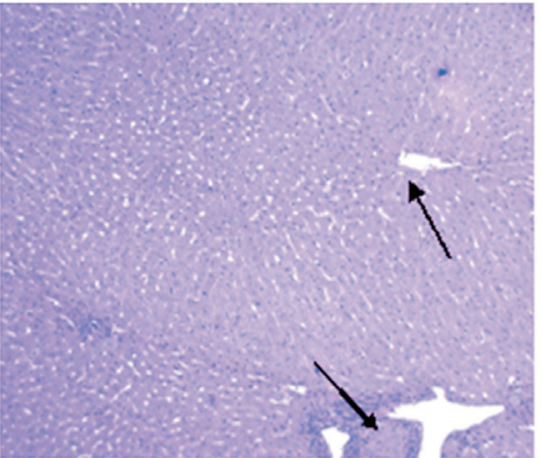

(C) H \& E X 200

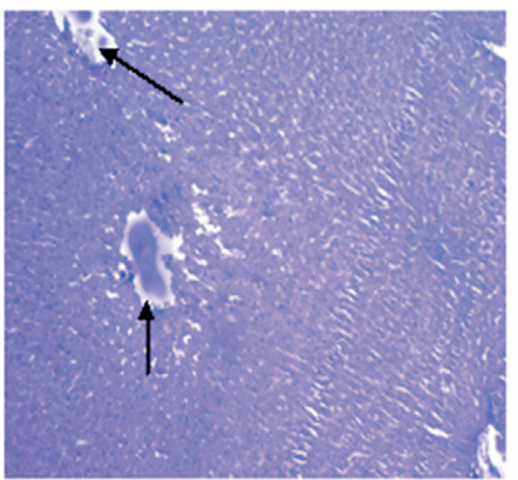

D. $\mathrm{H} \& \mathrm{E} \times 200$

Figure 5 - Photomicrograph (at H \& E X 150 and X200) of liver section of (C) negative control showing normal architecture formed of central vein ( $\uparrow$ ) and portal tract $(\tilde{\mathrm{n}})$ surrounded by cords and rows of normal hepatocytes. (D) Treated with $S$. canarius L-glutaminase showing variable sized central veins $(\uparrow)$ surrounded by cords and rows of hepatocytes. 

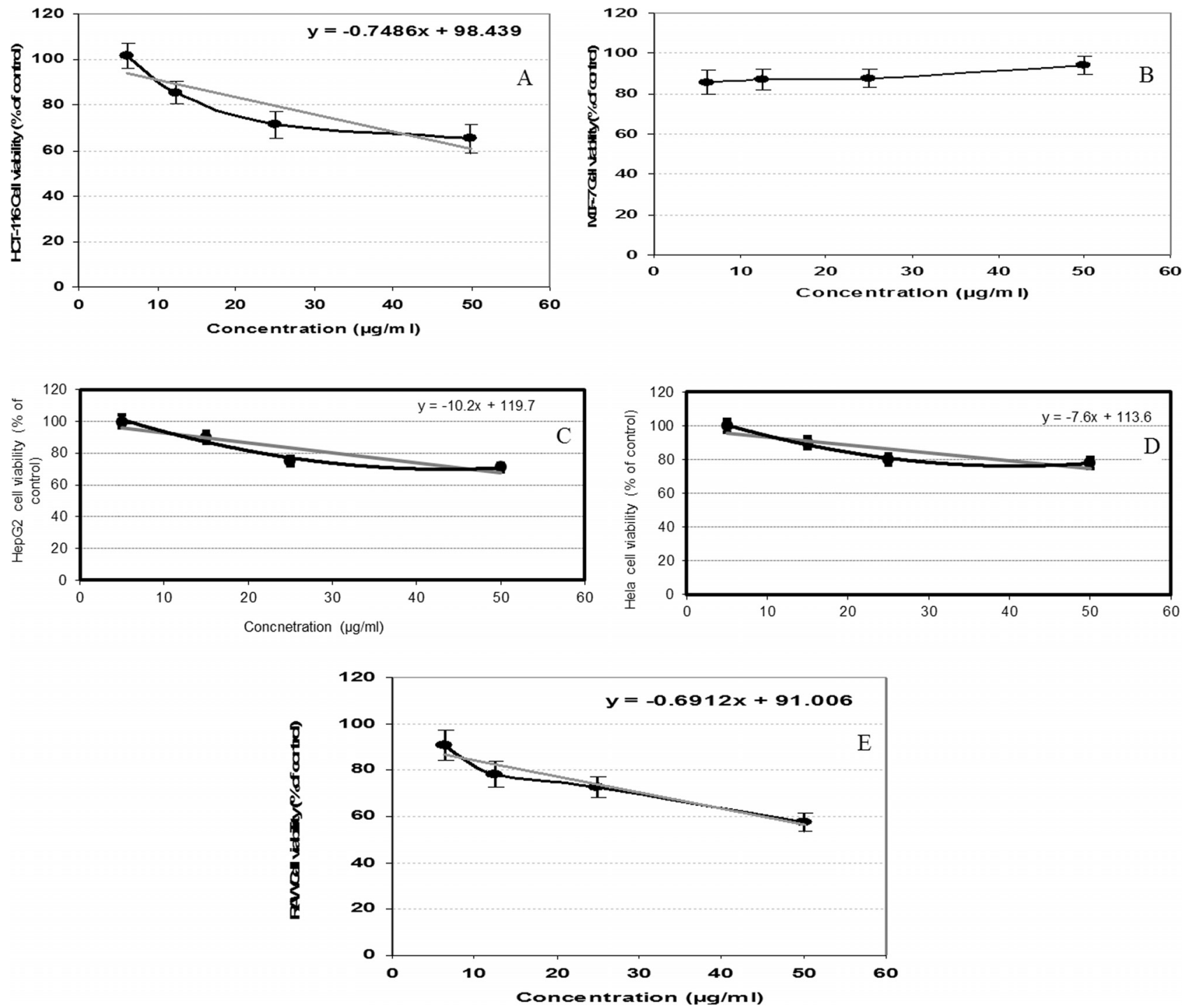

Figure 6 - Cytotoxic effect of S. canarius L-glutaminase on tumor cell lines using MTT assay (n=4), HCT-116 (A), MCF-7 (B), HepG2 (C), HeLa (D) and RAW 264.7 (E). Cells exposed to different concentrations of the drug for 48 hours. All data are expressed as the mean value of cell viability (\% of control) \pm S.E.s

vitro toxicity on Hep-2C cell lines (84\% survival) in comparison to commercial L-asparaginase preparation $(90 \%$ survival) obtained from E. coli. Also, Singh and Banik (2013) reported that the gradual inhibition in growth of hepatocellular carcinoma (Hep-G2) cell lines was found with IC50 value of $82.27 \mu \mathrm{g} / \mathrm{mL}$ in the presence of different doses of L-glutaminase $(10-100 \mu \mathrm{g} / \mathrm{mL})$. Moreover, Elshafei et al. (2014) recorded that the purified enzyme produced by Penicillium brevicompactum was inhibited the growth of human cell line hepatocellular carcinoma (Hep-G2), with $\mathrm{IC}_{50}$ value of $63.3 \mathrm{ug} / \mathrm{mL}$. Meanwhile, Nathiya et al. (2012) indicated a crucial role of Aspergillus flavus KUGF009 L-glutaminase in breast cancer (MCF7). Furthermore, Roberts et al. (1970) found that Lglutaminase from Pseudomonas sp. 7A is administered to inhibit HIV replication in infected cells. The enzyme brings about inhibition of tumor (melanoma) and DNA biosynthesis in affected cells. Glutaminase and asparaginase enzymes have produced prolonged remissions of certain experiment tumors (Wriston and Yellin, 1973). During treatment, plasma glutamine and asparagines are depleted. The degree of amino acid depletion depends on the kinetic properties of the enzymes, its biological half life in the animal, and the rate of input of the amino acid into circulation (Wriston and Yellin, 1973).

In conclusion, S. canarius (KC460654) had remarkable capacity to produce L- glutaminase. The purified enzyme showed a unique specificity to glutamine, broad $\mathrm{pH}$ stability, and high thermal stability. Also, the purified en- 
zyme is being promising candidate for application as antitumor agent in the future work.

\section{Acknowledgments}

The author would like to thank Dr. Akmal Sakr for collecting of samples, and staff members of Pathology Department, Faculty of Medicine, Zagazig University, Zagazig for their guidance for Histological studies.

\section{References}

Altschul SF, Madden TL, Schäffer AA et al. (1997) Gapped BLAST and PSI-BLAST: a new generation of protein database search programs. Nucleic Acids Res 17:389-402.

Amena S, Vishalakshi N, Prabhakar M et al. (2010) Production, purification and characterization of $\mathrm{L}$-aparaginase from Streptomyces gulbargensis. Braz J Microbiol 41:1517-8382.

Balagurunathan R, Radhakrishnan M, Somasundaram SR (2010) L- glutaminase sediments - selective isolation, semi Quantitative assay and characterization of potential strain. Aust $\mathrm{J}$ Basic Appl Sci 4:698-705.

Balagurunathan R, Subramanian A (1993) Studies on marine Streptomyces nigrifaciens (P9) I. Taxonomy and standardization of antibiotic production. Ciencias Marinas 19:435-443.

Baskerville A, Hambleton P, Benbough JE (1980) Pathological features of glutaminase toxicity. $\mathrm{Br} \quad \mathrm{J}$ Exp Pathol 61:132-138.

Birt JH (1967) International committee for standardization in hematology. 13:6-18.

Borek D, Michalska K, Brzezinski K et al. (2004) Expression, purification and catalytic activity of Lupinus luteus asparagines $\beta$-amidohydrolase and its Escherichia coli homolog. Eur J Biochem 271:3215-3226.

Dang CV (2010) Glutaminolysis: supplying carbon or nitrogen. Cell Cycle 19:3884-3886.

Devi S, Azmi W (2012) One step purification of glutaminase free L- asparaginase from Erwinia carotovora with anticancerous from activity. Int J Life Sci pharma Res 2:2250-2480.

Divya Teja D, Sri Devi V, Harsha N et al. (2014) Production of Lglutaminase from marine ecosystems and optimal conditions for maximal production by actinomycetes. International Journal of Advanced Research 2:485-491.

Dura MA, Flores M, Toldra F (2002) Purification and characterization of L-glutaminase from Debaryomyces spp. Int $\mathrm{J}$ Food Microbiol 76:117-126.

Elshafei AM, Hassan MM, Ali NH et al. (2014) Purification, kinetic properties and antitumor activity of L- glutaminase from Penicillium brevicompactum NRC829. British Micro Res J 4:97-115.

Hansen MB, Nielsen SE, Berg K (1989) Re-examination and further development of a precise and rapid dye method for measuring cell growth/cell kill. J Immunol Methods 119:203-210.

Iyer P, Singhal RS (2008) Production of glutaminase (E.C.3.2.1.5) from Zygosaccharomyces rouxii: Statistical optimization using response surface methodology. Bioresour Technol 99:4300-4307.
Kämpfer P (2006) The Family Streptomycetaceae. Part I, Taxonomy. In: M. Dworkin, S. Falkow, E. Rosenberg, K.-H. Schleifer, E. Stackebrandt (eds) The Prokaryotes. A Handbook on the Biology of Bacteria. Vol. 3. 3rd ed. Springer-Verlag, Berlin, pp. 538-604.

Kannan RR, Vincent SGP (2011) Molecular characterization of antagonistic Streptomyces isolated from a mangrove swamp. Asian J Biotechnol 3:237-245.

Kiruthika J, Saraswathy N (2013) production of L- glutaminase ant its optimization from a novel marine isolate Vibrio azureus JK-79. African J Biotech 12:6944-6953.

Krishnakumar S, Alexis R, Ravikumar S (2011) Extracellular production of L- Glutaminase by marine alkalophilic Streptomyces sp-SBU1 isolated from Cape Comorin coast. IJMS 40:717-721.

Kumar L, Singh B, Adhikari DK et al. (2012) A temperature and salt-tolerant L-glutaminase from gangotri region of uttarakhand himalaya: enzyme purification and characterization. Appl Biochem Biotechnol 166:1723-35.

Kumar SR, Chandrasekaran M (2003) Continuous production of L-glutaminase by an immobilized marine Pseudomonas sp BTMS-51 in a packed bed reactor. Process Biochemistry 38:1431-1436.

Kyoko K, Hrroaki N, An Y et al. (2004) Glutamninase, its gene and a method of producing it. U.S. Patent. Pat. No. 6830905 B2.

Lammeli UK (1970) Cleavage of structural proteins during the assembly of the head of bacteriophage T4. Nature (London), 227:680-685.

Landualt G, Guiochen G (1964) Separation of amines by gas liquid chromatography using Telfon support. J Chromatog 13:565-567.

Lazarus P, Panasci LC (1986) Characterization of L-theronine and Lglutamine transport in murine P388 leukemia cells in vitro. Presence of an N-like amino acid transport system. Biochem Biophys Acta 856:488-495.

Lehninger AL, Nelson DL, Cox MM (2005) Lehninger Principles of Biochemistry. $4^{\text {th }}$ ed. W.H. Freeman and Company, New York, pp 194-196.

Lowery OH, Rosebrouph AL, Farr NJ et al. (1951) Protein measurement with folin- phenol reagent. J Biol Chem 193:265-275.

Mohana Priya P, Radhakrishnan M, Balagurunathan R (2011) Production and optimization of L-asparaginase from Streptomyces sp (TA22) isolated from Western Ghats, India. J Chem Pharm Res 3:618-662.

Nagendra Prabhu G (1997) L-glutaminase production by marine Vibrio costicola under solid state fermentation. Ph.D. Thesis, Cochin University of Science \& Technology, Cochin, India.

Nandakumar R, Yoshimune K, Wakayama M et al. (2003) Microbial glutaminase: biochemistry, molecular approaches and applications in the food industry. J Molecular Catalysis B: Enzymatic 23:87-100.

Nathiya K, Nath SS, Angayarkanni J et al. (2012) In vitro cytotoxicity of L- glutaminase against MCF-7 cell line. Asian J Pharm Clinical Res 5:0974-2441.

Okami Y (1986) Marine microorganisms as a source of bioactive agents. Microb Ecol 12:65-78.

Pandey A (2003) Solid-state fermentation. Biochem Eng J 13:81. 
Pratt DS, Kaplan MM (2000) Evaluation of abnormal liver enzyme results in asymptomatic patients. N Engl J Med 342:1266-1271.

Ranjekar MK, Sridhar KR (2002) Occurrence and extracellular enzymatic potential of actinomycetes of a Thermal spring, Southern India. Asian J Microbiol Biotechnol Env Sci 4:59-64.

Reitman S, Frankel S (1957) A colorimetric method for the determination of serum glutamic oxalacetic and glutamic pyruvic transaminases. Amer J Clin Pathol 28:56-63.

Robert J, Allister JW, Sethuraman N et al. (2001) Genetically engineered glutaminase and its use in antiviral and anticancer therapy. U.S. Patent, No. 6312939.

Roberts J, Holcenberg JS, Dolowy WC (1970) Nature 227:1136.

Roy S, Maity P (2007) Modulation of Metastatic Potential of B16F10 Melanoma Cells by Acivicin: Synergistic Action of Glutaminase and Potentiation of Cisplatin Cytotoxicity. Asian Pacific Journal of Cancer Prevention 8:301-306.

Sabu A (2003) Sources, properties and applications of microbial therapeutic enzymes. Ind J Biotechnol 2:334-341.

Sabu A, Keerthi TR, Rajeev-Kumar S et al. (2000) L-glutaminase production by marine Beauveria sp. under solid state fermentation. Process Biochemi 35:705.

Sabu A, Nampoothiri KM, Pondey A (2005) L-Glutaminase as a therapeutic enzyme of microbial origin. In: Baredo JL (Editor), Methods in Biotechnology: Microbial Enzymes and Biotransformations. Humana Press Inc, Totowa, pp 75-90.

Salvatore D, Reagle D (2001) Theory and Problems of Statistics and Econometrics. $2^{\text {nd }}$ Ed. McGraw Hill, New York.

Senthil-Kumar M, Selvam K (2011) Isolation and Purification of High Efficiency L-asparaginase by Quantitative Preparative Continuous-elution SDS PAGE Electrophoresis. J Microbial Biochem Technol 3:73-83.

Singh P, Banik RM (2013) Biochemical characterization and antitumor study of L-glutaminase from Bacillus cereus MTCC 1305. Appl Biochem Biotechnol 171:522-31.

Sunil Dutt PLNSN, Siddalingeshwara KG, Karthic J1 et al. (2014) Antitumour property 1-glutaminase on from Aspergillus oryzae through submergrd fermentation. Int $\mathbf{J}$ Curr Microbiol App Sci 3:819-823.
Suresh Kumer S, Muthuvelayudham R, Viruthagiri T (2013) Statistical Optimization based Production of L- glutaminase by Serratia marcescens under submerged fermentation. Res J Chem Sci 3:43-53.

Tanaka S, Robinson EA, Appella E et al. (1988) Structures of Amidohydrolases. Aminoacid sequence of a glutaminaseasparaginase from Acinetobacter glutaminasificans and preliminary crystallographic data for an asparaginase from Erwinia crysanthemi. J Biological Chem 263:8583-8591.

Tay ST, Devi S, Puthcheary SD et al. (1995) Detection of haemolytic activity of Campylobacters by agarose haemolysis and microplate assay. J Med Microbiol 42:175-180.

Thadikamala S, Reddy SP (2011) Modeling the effect of L-glutamine, aeration and agitation regimes on production of L-glutaminase in stirred tank reactor using Bacillus subtilis RSP-glu. International Journal of Industrial Biotechnology 1:27-33.

Usha-Kiranmayi M, Sudhakar Poda, Vijayalakshmi M (2013) Production and optimization of L-asparaginase by an actinobacterium isolated from Nizampatnam mangrove ecosystem. J Environ Biol 35:799-805.

Wakayama M, Yamagata T, Kamemura A et al. (2005) Characterization of salt-tolerant glutaminase from Stenotrophomonas maltophilla NYW-81 and its application in Japanese soy sauce fermentation. J Ind Microbiol Biotechnol 32:383-390.

Wei XL, Wei JF, Li T et al. (2007) Purification, characterization and potent lung lesion activity of an L-amino acid oxidase from Agkistrodon blomhoffii ussurensis snake venom. Toxicon 50:1126-1139.

Whitaker JR (1972) Principles of enzymology for food sciences. In: R.E. Feeney and J.R. Whitaker (eds) Enzyme Inhibitors. Marcel Dekker, New York, pp 255-282.

Wriston JC, Yellin TO (1973) L-asparaginase: A review. Advan Enzymol 39:185-248.

Associate Editor: Lara Durães Sette

All the content of the journal, except where otherwise noted, is licensed under a Creative Commons License CC BY-NC. 